\title{
FRP REINFORCEMENT FOR CONCRETE STRUCTURES: STATE-OF-THE-ART REVIEW OF APPLICATION AND DESIGN
}

\author{
Eugenijus Gudonis ${ }^{\mathrm{a}}$, Edgaras Timinskas ${ }^{\mathrm{a}}$, Viktor Gribniak ${ }^{\mathrm{a}}$,, Gintaris Kaklauskas ${ }^{\mathrm{a}}$, \\ Aleksandr K. Arnautov' ${ }^{c}$ Vytautas Tamulènas ${ }^{\mathrm{a}}$ \\ ${ }^{a}$ Department of Bridges and Special Structures, Vilnius Gediminas Technical University, \\ Sauletekio al. 11, 10223 Vilnius, Lithuania \\ ${ }^{b}$ Civil Engineering Research Centre, Vilnius Gediminas Technical University, \\ Sauletekio al. 11, 10223 Vilnius, Lithuania \\ 'Institute of Polymer Mechanics, University of Latvia, Aizkraukles st. 23, 1006 Riga, Latvia
}

Received 17 September 2013; accepted 25 December 2013

\begin{abstract}
Fiber reinforced polymers (FRPs) are considered to be a promising alternative to steel reinforcement, especially in concrete structures subjected to an aggressive environment or to the effects of electromagnetic fields. Although attempts to develop effective reinforcement have been followed, the application of FRPs remains limited by the solution to simple structural problems that mainly appear due to the absence of design codes, significant variation in the material properties of FRP composites and limited knowledge gained by engineers as regards the application aspects of FRP composites and structural mechanics of concrete elements reinforced with FRPs. To fill the latter gap, the current state-of-the-art report is dedicated to present recent achievements in FRPs applying practice to a broad engineers' community. The report also revises the manufacturing process, material properties, the application area and design peculiarities of concrete elements reinforced with FRP composites. Along the focus on internal reinforcement, the paper overviews recent practices of applying FRP reinforced concrete (RC) elements in structural engineering. The review highlights the main problems restricting the application of FRPs in building industry and reveals the problematic issues (related to the material properties of the FRP) important for designing RC following the formulation of targets for further research.
\end{abstract}

Keywords: fiber reinforced polymers, FRP bars, reinforcement, material properties, application.

Reference to this paper should be made as follows: Gudonis, E.; Timinskas, E.; Gribniak, V.; Kaklauskas, G.; Arnautov, A. K.; Tamulènas, V. 2013. FRP reinforcement for concrete structures: state-of-the-art review of application and design, Engineering Structures and Technologies 5(4): 147-158.

http://dx.doi.org/10.3846/2029882X.2014.889274

\section{Introduction}

Steel and concrete are the principal materials of the industry of up-to-date construction. Nevertheless, there are applications that require an alternative material to be used. Fiber reinforced polymers (FRPs) are considered to be a promising alternative to steel reinforcement, especially in concrete structures subjected to an aggressive environment or to the effects of electroma- gnetic fields (Alsayed et al. 2000). Numerous concrete structures such as bridges, dams and off-shore structures are exposed to de-icing salts, combinations of temperature, moisture and chlorides that reduce the alkalinity of concrete and result in the corrosion of steel reinforcement.

Corresponding author:

E. Gudonis E-mail: eugenijus.gudonis@vgtu.lt 
At present, almost a half of the budget of construction industry is spent on the repair and reconstruction of the existing buildings (Cigna et al. 2003). In order to cope with corrosion problems, engineers have turned to alternative metallic reinforcement such as epoxy-coated steel bars, cathodic protection and increased thickness of concrete cover. While adequate in certain situations, such methods may still be unable to entirely eliminate the problems of steel corrosion (ACI 440 2006). Therefore, due to a non-corrosive nature, higher strength and lower unit weight of FRPs relative to conventional steel reinforcement as well as the use of FRP materials in an adverse environment is gaining recognition.

Different kinds of materials are used for producing FRP reinforcement. Carbon fiber reinforced polymers (CFRP) have the best mechanical properties (amongst other FRP composites), but materials for its production are hardly accessible. In terms of mechanical properties and production complexity, basalt (BFRP) and aramid (AFRP) bars are somewhere in the middle, but they are seldom used in practice. The bars of glass fiber reinforced polymers (GFRP) are the most popular among other FRP types due to the combination of relatively low-cost with environmental resistance to structural fibres. With high durability, GFRP bars have tensile strength up to 5-6 times higher than structural steel. However, a low elastic modulus of polymer composites (in respect to steel) generally leads to the increased deformations of GFRP reinforced elements. Thus, serviceability limit state often becomes the governing criterion in the design of such elements. A number of techniques have been proposed for predicting deformational response of FRP reinforced concrete (RC) elements (Faza, GangaRao 1992; Bischoff 2007), though a lack of experimental data is still evident.

Moreover, various types of surface coatings are used for producing composite bars. The surface treatment determines the quality of a bond between the bars and concrete matrix. A complex, uneven and rough shape of the bars ensures good bond properties; however, such surface treatment may result in more complex manufacturing processes. There is still no global consensus on the most effective shape of FRP bars. The standardization of the shape would allow a more extensive use of FRP reinforcement in construction.

Over the past decades, external bonding of FRP plates or sheets has been widely used for strengthen- ing RC structures. Due to high tensile strength and low weight (comparing to conventional steel), FRPs have become an ideal material for use in construction industry. Another advantage of FRP over steel as external reinforcement is easy handling; hence, minimal time and labour are required to implement them.

However, an engineer should be aware of the reliability of the applied strengthening technique. Frequently concrete cover separation or plate as well as interfacial debonding become the failure modes of FRP strengthening (Smith, Teng 2002; Oehlers et al. 2003). The behaviour of the interface between the FRP and concrete is the key factor controlling debonding failure in FRP-strengthened RC structures (Lu et al. 2005).

Although attempts to increase the effectiveness of FRP reinforcement have been followed, its application remains limited by the solution to simple structural problems. This might be related to the absence of design codes, significant variation in the material properties of FRP composites and limited knowledge gained by engineers on the application and structural aspects of FRP composites. The current state-of-art report is dedicated to fill the latter gap. The manuscript revises the manufacturing process, material properties, the application area and design peculiarities of concrete elements reinforced with FRP composites. Along the focus on internal reinforcement, the paper overviews recent practices of applying the FRP reinforced concrete (RC) element in structural engineering and formulates the main problems that restrict the application of FRPs in building industry. The review reveals problematic issues (related to the material properties of FRP) important for designing RC following the formulation of targets for further research.

\section{FRP materials, properties and types of manufacturing}

FRP composites are made from fiber, resin, interface, fillers and additives. The fibres of higher deformation modulus contribute to the mechanical strength of the FRP, whereas resin helps with transferring or distributing stress from one fiber to another to protect the fiber against environmental and mechanical damage. The interface between the fiber and matrix is known to significantly affect the performance of FRP composites. In addition to these three basic components (fibres, resins and interface), fillers serve to reduce cost and shrinkage. Additives assist in improving the 
mechanical and physical properties as well as the workability of composites.

The main part of FRP reinforcement is fibres. Table 1 presents the physical and mechanical properties of various kinds of fibres. There are four main materials used for producing fibres dominating in civil engineering industry: glass, carbon, aramid and basalt:

- Glass fiber reinforced polymers (GFRP). Relatively low cost comparing to other kinds of FRPs makes glass fibres the most commonly used in construction industry. However, a relatively low deformation modulus, low humidity and alkaline resistance as well as low long-term strength due to stress rupture are the main disadvantages of GFRP. In case of demand of better alkaline resistance, the so-called AR glass FRP is being used.

- Carbon fiber reinforced polymers (CFRP). These fibres have high deformation modulus and fatigue strength as well as do not absorb water. Though, a comparatively high energy requirement for the production of carbon fibres leading to high costs is one of the major disadvantages. Furthermore, their drawbacks include anisotropy (reduced radial strength) as well as potential galvanic corrosion in direct contact with steel (Carolin 2003).
- Aramid fiber reinforced polymers (AFRP). These fibres have high static and impact strengths. Nevertheless, their use is limited by reduced long-term strength (stress rupture) as well as sensitivity to UV radiation. Another drawback of aramid fibres is that they are difficult for cutting and processing (Tuakta 2005).

- Basalt fiber reinforced polymers (BFRP). Such fibres have excellent resistance to high temperatures and high tensile strength as well as good durability. Other advantages are high resistance to acids, superior electro-magnetic properties, resistance to corrosion, resistance to radiation and UV light and good resistance to vibration (Banibayat 2011).

Depending on the type of the FRP, the fibres combined with a matrix consisting of resins, fillers and additives are utilized for producing bars or sheets. Resins are the basic components of the matrix. There are two major types of resins: thermoplastic and thermosetting polymers. The latter are the most popular for producing FRP elements. Unlike thermoplastic polymers, once thermosetting polymers are cured, they cannot be reheated or reformed. Thermosets are usually brittle in nature, but offer high rigidity, thermal and dimensional stability, higher electrical, chemical and solvent

Table 1. Physical and mechanical properties of different FRPs

\begin{tabular}{|c|c|c|c|c|c|c|}
\hline \multirow{2}{*}{ Type of FRP } & Density & $\begin{array}{l}\text { Tensile } \\
\text { strength }\end{array}$ & $\begin{array}{l}\text { Deformation } \\
\text { modulus }\end{array}$ & Elongation & $\begin{array}{l}\text { Coefficient of thermal } \\
\text { expansion }\end{array}$ & \multirow{2}{*}{$\begin{array}{l}\text { Poisson's } \\
\text { ratio }\end{array}$} \\
\hline & $\mathrm{kg} / \mathrm{m}^{3}$ & $\mathrm{MPa}$ & $\mathrm{GPa}$ & $\%$ & $10^{-6} /{ }^{\circ} \mathrm{C}$ & \\
\hline Electrical-resistant $E$-glass & 2500 & 3450 & 72.4 & 2.4 & 5.0 & 0.22 \\
\hline High-strength $S$-glass & 2500 & 4580 & 85.5 & 3.3 & 2.9 & 0.22 \\
\hline Alkali-resistant $A R$-glass & 2270 & $1800-3500$ & $70-76$ & $2.0-3.0$ & $\mathrm{n} / \mathrm{a}$ & $\mathrm{n} / \mathrm{a}$ \\
\hline Carbon & 1700 & 3700 & 250 & 1.2 & -0.6 up to -0.2 & 0.20 \\
\hline Carbon (high-modulus) & 1950 & $2500-4000$ & $350-800$ & 0.5 & -1.2 up to -0.1 & 0.20 \\
\hline Carbon (high-strength) & 1750 & 4800 & 240 & 1.1 & -0.6 up to -0.2 & 0.20 \\
\hline Aramid (Kevlar 29) & 1440 & 2760 & 62 & 4.4 & $\begin{array}{l}-2.0 \text { longitudinal } \\
59 \text { radial }\end{array}$ & 0.35 \\
\hline Aramid (Kevlar 49) & 1440 & 3620 & 124 & 2.2 & $\begin{array}{l}-2.0 \text { longitudinal } \\
59 \text { radial }\end{array}$ & 0.35 \\
\hline Aramid (Kevlar 149) & 1440 & 3450 & 175 & 1.4 & $\begin{array}{l}-2.0 \text { longitudinal } \\
59 \text { radial }\end{array}$ & 0.35 \\
\hline Aramid (Technora H) & 1390 & 3000 & 70 & 4.4 & $\begin{array}{l}-2.0 \text { longitudinal } \\
59 \text { radial }\end{array}$ & 0.35 \\
\hline Aramid (SVM) & 1430 & $3800-4200$ & 130 & 3.5 & $\mathrm{n} / \mathrm{a}$ & $\mathrm{n} / \mathrm{a}$ \\
\hline Bazalt (Albarrie) & 2800 & 4840 & 89 & 3.1 & 8.0 & $\mathrm{n} / \mathrm{a}$ \\
\hline
\end{tabular}


resistance. Table 2 gives the physical and mechanical properties of the most widely used thermosets.

These are the following processes used for producing FRP structural elements (Hoffard, Malvar 2005; Banibayat 2011):

- Pultrusion involves pulling rolls of a material through a series of tooling devices, resin baths and heated dies to merge, shape and cure the resulting composite into a solid part. Pultrusion produces continuous lengths of structural shapes with constant cross-sections.

- Hand lay-up/contact moulding is used for fabricating face skin over a panel core. Resin is manually applied to the core. The assembly of pre-cured face sheets is then placed on the top of a wet corrugated sheet of the core to produce a sandwich panel. The hand lay-up method lends itself to composite fabrication and repair in the field.

- Vacuum assisted resin transfer moulding (VARTM) uses a vacuum to infuse resin into reinforcement fibres or fabrics that are placed in an evacuated mold. The mixture is allowed to cure under the vacuum. The main advantage of VARTM over pultrusion is the unlimited size and geometry possibilities of the components.

- The automated wet lay-up manufacturing process essentially consists of laying up the fibres impregnated with polymeric resin such that it yields usable composite bars when cured. FRP bars are made using a programmable arm with controlled movement in three orthogonal directions to manufacture the desired lengths to

Table 2. Physical and mechanical properties of polyester, epoxy and vinyl-ester resins

\begin{tabular}{|l|c|c|c|}
\hline \multirow{2}{*}{\multicolumn{1}{|c|}{ Properties }} & \multicolumn{3}{c|}{ Thermosetting resins } \\
\cline { 2 - 4 } & Polyesters & Epoxy & Vinyl-ester \\
\hline Density, kg/m ${ }^{3}$ & $1200-1400$ & $1200-1400$ & $1150-1350$ \\
\hline Tensile strength, $\mathrm{MPa}$ & $34.5-104$ & $55-130$ & $73-81$ \\
\hline $\begin{array}{l}\text { Deformation } \\
\text { modulus, GPa }\end{array}$ & $2.1-3.45$ & $2.75-4.10$ & $3.0-3.5$ \\
\hline Poisson's ratio & $0.35-0.39$ & $0.38-0.40$ & $0.36-0.39$ \\
\hline $\begin{array}{l}\text { Coefficient of thermal } \\
\text { expansion, } 10^{-6} /{ }^{\circ} \mathrm{C}\end{array}$ & $55-100$ & $45-65$ & $50-75$ \\
\hline Saturation, \% & $0.15-0.6$ & $0.08-0.15$ & $0.14-1.30$ \\
\hline
\end{tabular}

the required shape. The cost of producing FRP bars employing this method is believed to be reduced because the production method is simple and designed to reduce human involvement.

In addition to the already mentioned properties of the FRP, it is essential to secure sufficient bond strength between the reinforcement and structural elements. Depending on the application, FRP reinforcement can be categorized into two main groups: internal and external. Internal reinforcement is usually manufactured in the shape of the bars. As shown in Fig. 1, the core of the bars is made of fibres and resin and the surface might be deformed or sand-coated. The technology of surface coating is very important for bonding properties. Sand-coated surfaces often do not assure sufficient bond quality that leads to the slip of reinforcement in concrete. Therefore, the deformed surface is more prominent for structural application. Recent investigations by the authors (Gribniak et al. 2013; Timinskas et al. 2013) have revealed that grooved surface (for instance, Schöck ComBAR) reinforcement is characterized by the high quality (strength) of the bond. It could be explained by a well-balanced shape of the surface of the bar: the shear strength of concrete in the grooves is proportional to bar surface-to-core connection strength (Fig. 2).

Unlike internal reinforcement utilized in the production of new structures where bond quality mostly depends on the surface production technology external reinforcement is generally used for strengthening the existing structural elements. Gluing FRP sheets or strips (Fig. 3) onto damaged elements result in inadequate bond strength.

The applicability and efficiency of strengthening with FRP composites depend mainly on the material and type of the member to be strengthened. In general, the applications where accessibility conditions allow wrapping a member with FRP composites, such as FRP wrapping of RC columns, has no problem regarding a debonding issue (Buyukozturk et al. 2004). Considering the use of FRPs for external strengthening of the external reinforcement of other types of concrete elements, Xiong et al. (2007), Kim et al. (2008a, b), Skuturna et al. (2008), Diab et al. (2009), and Daugevičius et al. (2012) found that additional anchoring was essential in order to assure FRP-to-concrete bond strength. 

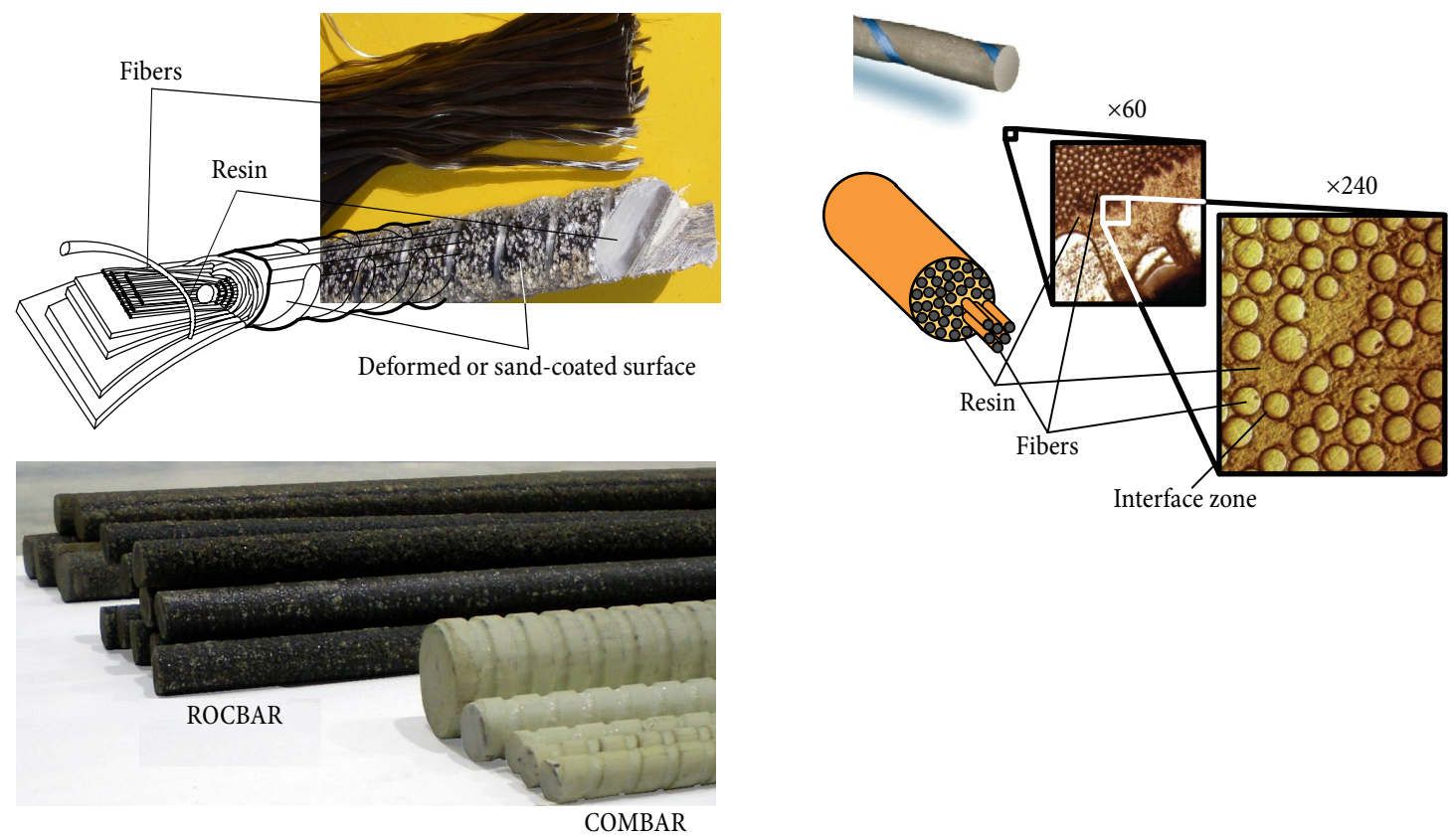

Fig. 1. The structure and coating of FRP bars

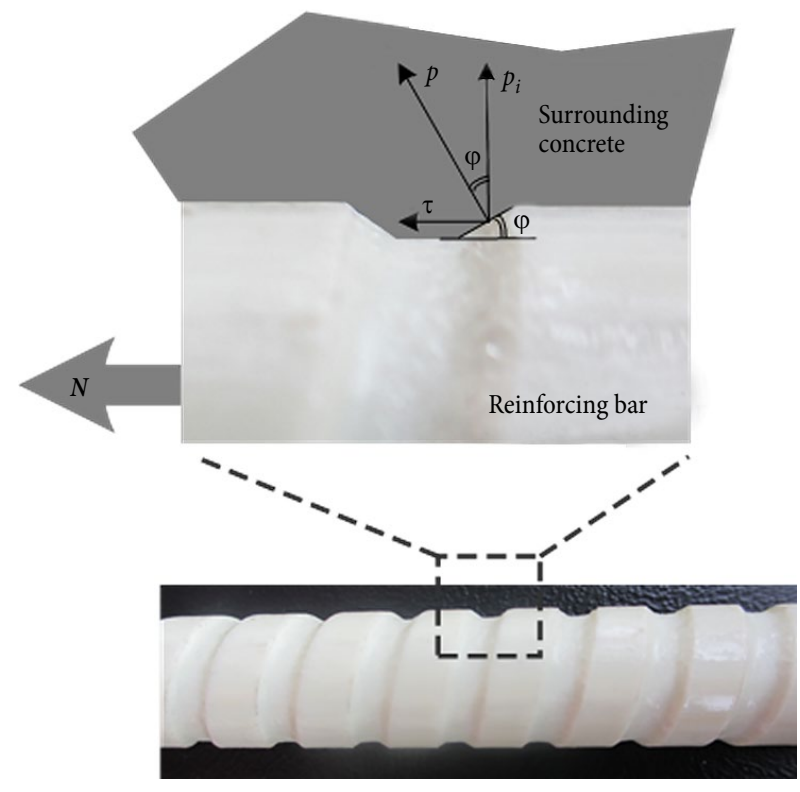

Fig. 2. Bond action of Schöck ComBAR reinforcement

\section{Structural applications}

There is a huge variety of applications in which FRPs can be effectively used in structural engineering. FRP composites are applied both for new construction and strengthening or repairing the existing buildings. Generally, two main categories of FRP application can be defined: FRP bars, rods and tendons as an internal reinforcement as well as FRP sheets, wraps and laminates as an external reinforcement. This section outli-

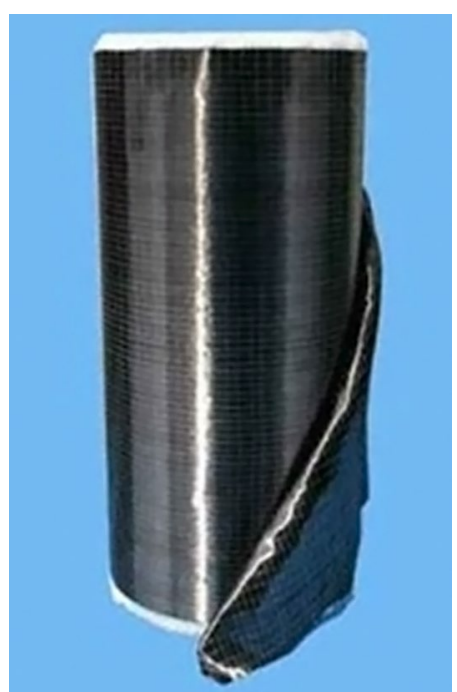

Fig. 3. Carbon FRP sheet for external structural reinforcement (photo form http://www.fortecstabilization.com)

nes some of the most common uses of FRPs in civil infrastructure.

FRP reinforcing bars comprising FRP grids have been extensively used as an internal reinforcement for a number of concrete structures, including bridges, tunnels, underground precast chambers and highway pavements. FRP grids are often applied as a lightweight reinforcement in curtain walls where lower requirements for concrete cover results in thinner and lighter 
facade panels. Due to their excellent resistance for corrosion, the internal FRP reinforcement has been widely employed in marine structures and systems for slope protection and stability. Moreover, FRP composites are characterized by having inertness for electricmagnetic inductivity, thus, are utilized for producing maglev rails.

Another high promising potential use of FRP materials is to fabricate specific structural components entirely out of the FRP, such as bridge decks, girders, etc. or to use prefabricated FRP stay-in-place reinforcement panels for the construction of the decks of concrete bridges (Fig. 4). The replacement of conventional concrete bridge decks with FRP composite bridge decks suggests a viable solution to the rehabilitation of the existing bridges. The benefits of FRP replacement decks embrace low weight (increasing the live load capacity of the bridge structure), increased durability (highly resistant to corrosion and fatigue), lower or competitive life-cycle cost and rapid bridge construction using large prefabricated FRP reinforcements.

FRP materials are becoming increasingly popular for repairing and strengthening concrete structures. In the interest of the increased flexural strength and rehabilitation of RC elements, the technique of near surface mounted (NSM) FRP rods are used. Moreover, FRP plates or sheets are bonded to the exterior of RC members following the wet lay-up procedure that helps in increasing their bending or shear capacity (Fig. 5).

In order to increase the strength and ductility of RC columns, FRP sheets (wraps) can be applied as a confining reinforcement applied around them. Another FRP application as an external reinforcement is concrete filled FRP tubes. Furthermore, the FRP outer shell protects the concrete core from exposure to harsh environmental conditions and provides confinement to concrete thereby increasing the strength and ductility of the pile. Summarizing the major FRP application options, the utilization of FRP is classified in Table 3.

In spite of extensive attempts to apply FRP reinforcement in civil engineering, there are some aspects limiting this process. The two main reasons are as follows:

- The design guides to FRP reinforced concrete elements in the USA, Canada, Japan and Italy have been provided, though, no design codes for FRP reinforcement have been developed. Due to the absence of design codes, in most cases, the responsibility of structural safety and serviceability fully lies on the designer.

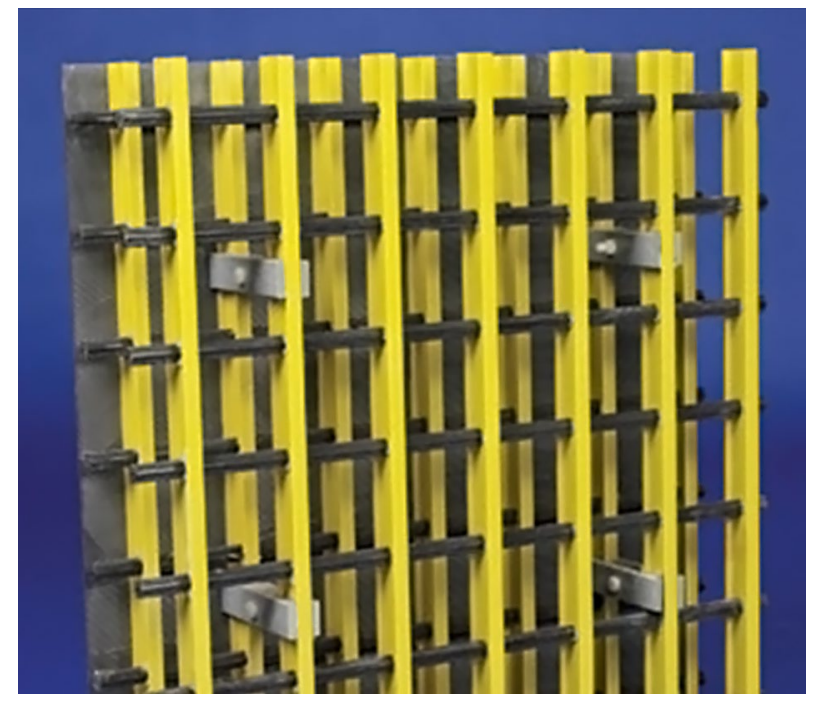

Fig. 4. Fiberglass grid form for bridge decks (photo from http://www.gefinc.com)

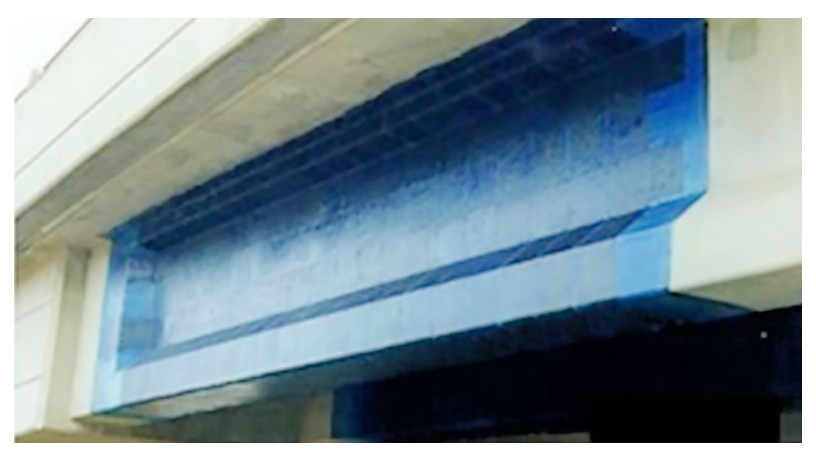

Fig. 5. Externally-bonded carbon FRP sheets for shear strengthening of a reinforced concrete bridge girder (photo from http://www.fhwa.dot.gov/everydaycounts/ technology/bridges/pbeswebinartraining/s3_m9.cfm)

- There are not enough reliable experimental data on the long-term degradation of the mechanical properties of FRP materials. Therefore, common design practice is based on the increased values of safety factors leading to higher costs of the elements with FRP reinforcement and making such constructions economically inefficient.

\section{Peculiarities of structural application and design}

Structural elements reinforced with FRPs may deteriorate due to environmental, physical or chemical conditions thus leading to the loss of strength and stiffness. The degree of damage and deterioration depends on a variety of factors such as the type and volume of fibres and resin matrix, the exposed environment and the manufacturing process (Malvar 1998). 
Table 3. Application of internal and external FRP reinforcements

\begin{tabular}{|c|c|c|c|c|c|}
\hline \multicolumn{3}{|c|}{ Internal } & \multicolumn{3}{|c|}{ External } \\
\hline Reference & Reinforcement & Application & Reference & Reinforcement & Application \\
\hline \multirow[t]{2}{*}{ Rizkalla et al. (1998) } & \multirow{2}{*}{$\begin{array}{c}\text { One- } \\
\text { dimensional } \\
\text { (longitudinal) } \\
\text { bars }\end{array}$} & $\begin{array}{l}\text { Bridge deck } \\
\text { slabs }\end{array}$ & $\begin{array}{l}\text { Teng et al. (2007); } \\
\text { Fam et al. }(2003 \mathrm{a}, \mathrm{b})\end{array}$ & $\begin{array}{l}\text { FRP tubes } \\
\text { (outer shells) }\end{array}$ & $\begin{array}{c}\text { Precast piles, } \\
\text { concrete-filled } \\
\text { fender piles and } \\
\text { columns }\end{array}$ \\
\hline & & Barrier walls & $\begin{array}{c}\text { Shahawy et al. } \\
(1996 a, b)\end{array}$ & $\begin{array}{l}\text { Sheets and } \\
\text { pre-cured } \\
\text { laminates }\end{array}$ & $\begin{array}{c}\text { Flexural } \\
\text { strengthening of } \\
\text { slabs and beams } \\
\end{array}$ \\
\hline $\begin{array}{l}\text { Cheng, Karbhari (2006); } \\
\text { Rizkalla, Tadros (1994) }\end{array}$ & $\begin{array}{l}\text { Strands and } \\
\text { rods }\end{array}$ & $\begin{array}{l}\text { Pre-stressed } \\
\text { girders }\end{array}$ & $\begin{array}{l}\text { Hutchinson et al. } \\
\qquad(2003) ; \\
\text { Teng et al. }(2003)\end{array}$ & FRP sheets & $\begin{array}{c}\text { Shear } \\
\text { strengthening } \\
\text { of girders } \\
\end{array}$ \\
\hline $\begin{array}{l}\text { Benmokrane et al. } \\
\quad(2006,2000) ; \\
\text { Lopez-Anido (1997) }\end{array}$ & \multirow{2}{*}{$\begin{array}{l}\text { Two- } \\
\text { dimensional } \\
\text { grids }\end{array}$} & $\begin{array}{l}\text { Bridge deck } \\
\text { slabs and deck } \\
\text { systems }\end{array}$ & $\begin{array}{l}\text { El-Hacha, Rizkalla } \\
\text { (2004); } \\
\text { De Lorenzis, Nanni } \\
(2002) \\
\end{array}$ & $\begin{array}{l}\text { Near surface } \\
\text { mounted } \\
(\mathrm{NSM}) \text { rods } \\
\text { and bars } \\
\end{array}$ & $\begin{array}{l}\text { Repair of } \\
\text { concrete bridge } \\
\text { girders }\end{array}$ \\
\hline Benmokrane (1999) & & $\begin{array}{c}\text { Underground } \\
\text { structures, } \\
\text { chambers } \\
\end{array}$ & \multirow{2}{*}{$\begin{array}{c}\text { Ilki et al. (2008); } \\
\text { Demers et al. (2003); } \\
\text { Neale (2000); } \\
\text { Seible et al. }(1997)\end{array}$} & \multirow{2}{*}{$\begin{array}{c}\text { Wrapping } \\
\text { sheets, jackets }\end{array}$} & \multirow{2}{*}{$\begin{array}{l}\text { Seismic retrofit } \\
\text { of columns and } \\
\text { special structures }\end{array}$} \\
\hline Rizkalla et al. (2006) & Shear stirrups & $\begin{array}{l}\text { Pre-stressed } \\
\text { girders }\end{array}$ & & & \\
\hline Eddie et al. (2001) & Dowels & $\begin{array}{l}\text { Highway } \\
\text { pavements }\end{array}$ & \multirow{2}{*}{$\begin{array}{c}\text { Niroomandi et al. } \\
\text { (2010); } \\
\text { Engindeniz et al. (2005) }\end{array}$} & \multirow[b]{2}{*}{ FRP sheets } & \multirow{2}{*}{$\begin{array}{c}\text { Joint } \\
\text { strengthening } \\
\text { of RC structures }\end{array}$} \\
\hline $\begin{array}{c}\text { Keller (2003); } \\
\text { Tezuka (1994); } \\
\text { Mufti et al. (1991) }\end{array}$ & $\begin{array}{l}\text { Prestressing } \\
\text { tendons }\end{array}$ & $\begin{array}{c}\text { Bridge } \\
\text { cables, cable } \\
\text { reinforcement }\end{array}$ & & & \\
\hline
\end{tabular}

Most composites exhibit long-term static strength that is significantly lower than short-term strength. For Polyester E-glass tendons, long-term static strength at 10,000 hours (about 1 year) has been reported to be $70 \%$ of short-term static strength (Wolff, Miesser 1989; Taerwe 1993). Sultan et al. (1995) report that the remaining strength of hand laid-up fibreglass after 10 to 15 years becomes $40 \%$ of short-term static strength. Slattery (1994) reports that long-term tests on fibreglass composites with epoxy resin showed a failure of about a half of the samples tested at the sustained stress of only $50 \%$ of ultimate after about 7 years. Some of the samples ruptured at levels as low as $33 \%$ of ultimate. According to Hawkins et al. (1996), E-glass composite wraps applied as confinement to circular highway columns failed in 3 years under sustained stress around $32 \%$ of the manufacturer's reported strength. For Kevlar fibres, 100-year sustained strength is around $60 \%$ of short-term strength (Taerwe 1993; Horn et al. 1977). Test data on carbon fibres show very few failures after several years and the sustained stress of $80 \%$ of the short-term ultimate value (Slattery 1994).

Tests on the aramid bar showed sustained to the short-term strength ratios of $75 \%, 70 \%, 60 \%$ and $50 \%$ for exposure to $20^{\circ} \mathrm{C}$ air and $20^{\circ} \mathrm{C}, 40^{\circ} \mathrm{C}$ and $60{ }^{\circ} \mathrm{C}$ alkaline environments respectively (at 10,000 hours) (Scheibe, Rostasy 1995). The estimated 100 -year sustained strength of an aramid rod decreased from $60 \%$ in air to $50 \%$ of short-term strength in an alkaline environment (Horn et al. 1977; Gerritse 1992; Gerritse, Den Uijl 1995). Dolan et al. (1997) found the longterm strength (at 5500 hours and for GFRP tendons embedded in concrete) of about $55 \%$ of the short-term value.

Attention should be paid to protect FRP materials, particularly glass and aramid bars, from the alkali environment in concrete. In case of CFRP, a decrease in strength and stiffness might reach about 20\% (Takewaka, Khin 1996) while the type of glass fibres, resin and the manufacturing process may lower tensile capacity even in the range of $25-100 \%$ (Rostasy 1997). In addition to that, according to Nkurunziza et al. (2005), the reduction of strength due to alkali can be influenced by a high temperature and stress level. Another report states that a reduction in the tensile strength of $41 \%$ was observed after alkali exposure for 42 days at a temperature of $60{ }^{\circ} \mathrm{C}$ (Micelli, Nanni 2004). Regarding AFRP, the tensile strength and stiffness of AFRP 
rods in elevated temperature alkaline solutions either with or without tensile stress have been reported to decrease between $10-50 \%$ and $0-20 \%$ of the initial values respectively (Takewaka, Khin 1996; Rostasy 1997; Sen et al. 1998). Protection from the alkali environment may be assured at the manufacturing stage of FRP by using proper coating materials. However, the coated surface may be damaged under construction. Moreover, fibres are deteriorated due to chemical attack through the uncovered (by cutting) endings of the bars. Thus, the construction of the elements with GFRP or AFRP bars requires increased accuracy.

A relatively low modulus of elasticity (comparing to steel) is characteristic of the most of FRP bars (Fig. 6). This leads to smaller structural rigidity provided by these bars in respect to RC elements. Moreover, the deformation modulus might significantly decrease in time. According to Arockiasamy et al. (2000), an increase in deflections over the instantaneous values for a period of 470 and 610 days is up to $115 \%$ and $125 \%$ respectively.

Structural elements with FRP reinforcement with a low modulus of elasticity may not meet serviceability (limitation of strain and deflection) requirements. In order to solve this problem, the design of FRP reinforced elements often is based on the condition of relative stiffness $n_{f} \times \rho$ (FRP bar-to-concrete deformation modulus ratio multiplied by longitudinal reinforcement ratio) equivalent to conventionally (with steel bars) reinforced elements (Baena et al. 2012). As can be observed from Fig. 6, such a design, depending on the type of FRP reinforcement, may lead to 2-3 times

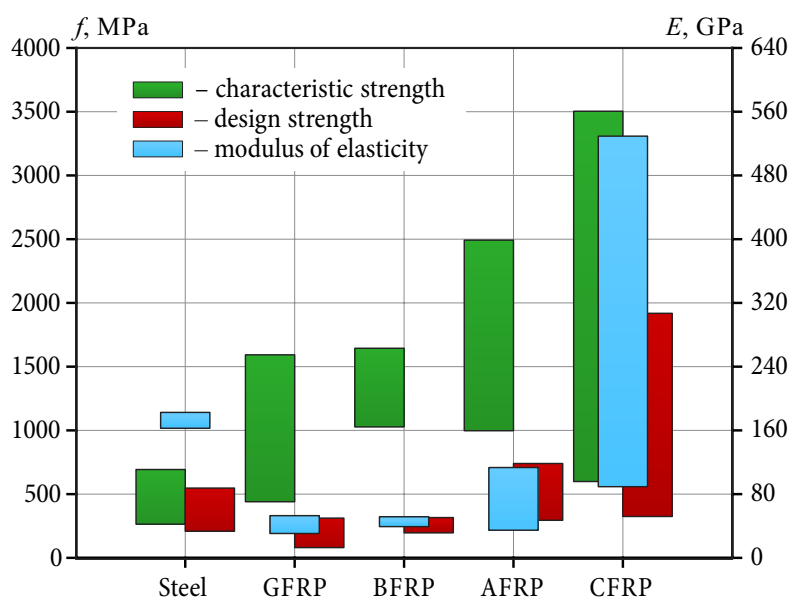

Fig. 6. Comparison of characteristic and design tensile strength and elasticity modulus of different types of reinforcement (Timinskas et al. 2013) increased cross-area of FRP bars. Consequently, this increases the cost of the structural element.

The effect of ultraviolet (UV) radiation is another aspect that is of vital importance for applying FRP composites as an external reinforcement (Bank et al. 1995; Odagiri et al. 1997). Aramids are most vulnerable to UV attack. A thin Kevlar 29 fabric exposed to Florida sun for 5 weeks lost $49 \%$ of its strength (DuPont 1992). Tests on FRP materials exposed to UV rays carried out by Kato et al. (1997) and Tomosawa et al. (1998) have shown AFRP rods having around 13\% reduction in tensile strength after $2500 \mathrm{~h}$ of exposure, and GFRP rods experiencing $8 \%$ reduction after $500 \mathrm{~h}$ (no reduction thereafter). Glass and particularly carbon FRPs are less sensitive to the effects of UV radiation, though the majority of resins will be affected by UV. To prevent the effect of UV radiation, structural measures or material modifications (extra matrix additives, pigmented gel coatings, painting) are used.

Design recommendations for FRP reinforced concrete elements exist in the USA (ACI 440 2006), Canada (CSA 2010, 2012), Japan (JSCE 1997) and Italy (CNR 2007). The International Federation for Structural Concrete developed a technical report considering the application of FRP reinforcement in RC structures (FIB 2007). However, there are no design codes for such type of the reinforcement. The current European (CEN 2004), American (ACI 318 2011) and Russian (NIIZhB 2006) design codes of structural concrete are adapted to the elements reinforced with steel bars, but, may be inadequate for designing structures with composite bars.

As noted before, the lack of reliable experimental data results in the increased values of safety factors. According to ACI 440 recommendations, in order to ensure the serviceability limit state of the existing structures, a characteristic value of the tensile strength of GFRP, AFRP and CFRP has to be reduced by $80 \%, 70 \%$ and $45 \%$ respectively. Following the report (Schöck 2006), despite the high (well above $1000 \mathrm{MPa}$ ) short-term tensile strength of ComBAR bars, a reduction in the strength value is recommended to be $435 \mathrm{MPa}$ for design purposes. For the deformation analysis of FRP RC elements, the Italian design guide (CNR 2007) applies empirical expressions from the Eurocode 2 (CEN 2004) with a multiplier that simply increases the deformations of a cracked element twofold. However, recent investigations by the authors (Gribniak et al. 2013) have revealed that such 
methodology is too rough, as deformations mainly depend on the bond properties of FRP bars embedded in concrete. Similar results were obtained by Miàs et al. (2013b) who investigated long-term deflections of FRP RC elements. However, it is important to note that a long-term deflection increment depended on the longitudinal reinforcement ratio growing with the increased cross-section of FRP reinforcement (Miàs et al. 2013a).

In fact, the design of concrete elements reinforced with FRP bars should be based on the experimental results of structural stiffness and bond properties between FRP bars and concrete. This problem can be solved by developing a standard shape of FRP bars and anchoring measures for the external reinforcement. The standardization of the shape would allow a more extensive use of FRP reinforcement in construction industry. However, having in mind that the development of the shape of steel bars took over 100 years, it is believed that the uniform methodology for FRP reinforcement would be developed in the middle of this century.

\section{Conclusions}

On the basis of the performed extensive analysis of literature sources, it can be concluded that for designing FRP RC elements, the main attention should be paid to the following factors:

1. Long-term degradation of mechanical properties. Depending on the type of FRP reinforcement, longterm strength might decrease two-three times (in respect to the short-term value). The maximum decrement of strength is related to GFRP; however, other fibres also are vulnerable for the time effect. Moreover, creep is characteristic for most of the polymer resins applied in FRP. Therefore, a designer should be aware of the increment of deformations in time of concrete elements with FRP reinforcement.

2. Proper selection of FRP material under severe environmental conditions. Most of the materials used for producing FRP are not resistant to specific environmental actions. For instance, glass fibres are not alkali-resistant; UV radiation is harmful to the mechanical properties of most of polymer resins. An adequate (in respect of the current environmental actions) selection of FRP materials would improve the exploitation properties of concrete structures.
3. Bond properties as the governing criteria for deformational analysis. In most cases, the design of FRP RC elements is based on the application of the increased values of safety factors. However, recent investigations by the authors have revealed that such methodology is too rough as deformations mainly depend on the bond properties of FRP composites. Thus, it can be stated that, in order to increase the effectiveness of applying structural composites, design practice has to be based on experimental tests referring to the bond properties of particular FRP materials.

The review has revealed that further research should aim at:

- experimental investigation into long-term mechanical processes taking place in concrete elements with FRP reinforcement;

- development of the standard shape of internal FRP bars and anchoring measures for external reinforcement;

- development of design procedures for the application of unified internal and external reinforcements.

\section{Acknowledgements}

The authors gratefully acknowledge financial support provided by the Research Council of Lithuania (Research Project MIP-083/2012). Viktor Gribniak and Aleksandr K. Arnautov wish to acknowledge the support by the European Social Fund (Project No. 2013/0019/1DP/1.1.1.2.0/13/APIA/VIAA/062).

\section{References}

ACI Committee 318. 2011. Building Code Requirements for Structural Concrete, ACI 318M-11. Farmington Hills, Michigan: ACI (American Concrete Institute).

ACI Committee 440. 2006. Guide for the Design and Construction of Structural Concrete Reinforced with FRP Bars, ACI 440.1R-06. Michigan, Farmington Hills: ACI (American Concrete Institute).

Alsayed, S. H.; Al-Salloum, Y. A.; Almusallam, T. H. 2000. Performance of glass fiber reinforced plastic bars as a reinforcing material for concrete structures, Composites Part B: Engineering 31(6): 555-567.

http://dx.doi.org/10.1016/S1359-8368(99)00049-9

Arockiasamy, M.; Chidambaram, S.; Amer, A.; Shahawy, M.; 2000. Time-dependent deformations of concrete beams reinforced with CFRP bars, Composites Part B: Engineering 31(6): 577-592.

Baena, M.; Torres, L.; Turon, A.; Miàs, C. 2012. Analysis of cracking behaviour and tension stiffening in FRP reinforced 
concrete tensile elements, Composites Part B: Engineering, $1360-1367$.

Banibayat, P. 2011. Experimental investigation of the mechanical and creep rupture properties of basalt fiber reinforced polymer (BFRP) bars: Doctoral dissertation, The University of Akron.

Bank, L. C.; Gentry, T. R.; Barkatt, A. 1995. Accelerated test methods to determine the long-term behavior of FRP composite structures: environmental effects, Journal of Reinforced Plastics and Composites 14(6): 559-587.

Benmokrane, B. 1999. Hydro-Québec upgrades chambers. FRP International, 5.

Benmokrane, B.; El-Salakawy, E.; El-Ragaby, A.; Lackey, T. 2006. Designing and testing of concrete bridge decks reinforced with glass FRP bars, Journal of Bridge Engineering 11(2): 217-229.

http://dx.doi.org/10.1061/(ASCE)1084-0702(2006)11:2(217)

Benmokrane, B.; Rahman, H.; Mukhopadhyaya, P.; Masmoudi, R.; Chekired, M.; Nicole, J.; El-Safty, A. 2000. Use of fibre reinforced polymer reinforcement integrated with fibre optic sensors for concrete bridge deck slab construction, Canadian Journal of Civil Engineering 27(5): 928-940. http://dx.doi.org/10.1139/100-029

Bischoff, P. H. 2007. Deflection calculation of FRP reinforced concrete beams based on modifications to the existing Branson equation, Journal of Composites for Construction 11(1): 4-14.

http://dx.doi.org/10.1061/(ASCE)1090-0268(2007)11:1(4)

Buyukozturk, O.; Gunes, O.; Karaca, E. 2004. Progress on understanding debonding problems in reinforced concrete and steel members strengthened using FRP composites, Construction and Building Materials 18(1): 9-19. http://dx.doi.org/10.1016/S0950-0618(03)00094-1

Carolin, A. 2003. Carbon fibre reinforced polymers for strengthening of structural elements: Doctoral thesis, Division of Structural Engineering, Department of Civil and Mining Engineering, Lulea University of Technology, Sweden. 194 p.

Cheng, L.; Karbhari, V. M. 2006. New bridge systems using FRP composites and concrete: a state-of-the-art review, Progress in Structural Engineering and Materials 8(4): 143-154. http://dx.doi.org/10.1002/pse.221

CEN (Comité Européen de Normalisation). 2004. Eurocode 2: Design of Concrete Structures - Part 1: General Rules and Rules for Buildings, EN 1992-1-1:2004. Brussels: CEN.

Cigna, R.; Andrade, C.; Nürnberger, U. 2003. COST Action 521, Corrosion of steel in reinforced concrete structures, Final report. European Communities. Luxembourg.

CNR. 2007. Guide for the Design and Construction of Concrete Structures Reinforced with Fiber-Reinforced Polymer Bars, CNR-DT 203/2006. Italy: CNR (Advisory Committee on Technical Recommendations for Construction).

CSA. 2010. Specification for Fibre-Reinforced Polymers, CSAS807-10. Toronto, Canada: CSA (Canadian Standards Association).

CSA. 2012. Design and construction of building structures with fibre-reinforced polymers, CAN/CSA S806-12. Canada: CSA (Canadian Standards Association).

Daugevičius, M.; Valivonis, J.; Marčiukaitis, G. 2012. Deflection analysis of reinforced concrete beams strengthened with carbon fibre reinforced polymer under long-term load action,
Journal of Zhejiang University SCIENCE A 13(8): 571-583. http://dx.doi.org/10.1631/jzus.A1100317

De Lorenzis, L.; Nanni, A. 2002. Bond between near-surface mounted FRP rods and concrete in structural strengthening, ACI Structural Journal 99(2): 123-132.

Demers, M.; Popovic, A.; Neale, K.; Rizkalla, S.; Tadros, G. 2003. FRP Retrofit of the ring-beam of a nuclear reactor containment structure, in Rizkalla, S.; Nanni, A. (Eds.). Field Applications of FRP Reinforcement: Case Studies ACI SP-215. ACI, Farmington Hills, 303-316.

Diab, H.; Wu, Z.; Iwashita, K. 2009. Short and long-term bond performance of prestressed FRP sheet anchorages, Engineering Structures 31(5): 1241-1249.

http://dx.doi.org/10.1016/j.engstruct.2009.01.021

Dolan, C. W.; Leu, B. L.; Hundley, A. 1997. Creep-rupture of fiber reinforced plastics in a concrete environment, in Proceedings of the Third International Symposium on Non-Metallic (FRP) Reinforcement for Concrete Structures (FRPRCS-3) 2: 187-194.

Eddie, D.; Shalaby, A.; Rizkalla, S. 2001. Glass fiber-reinforced polymer dowels for concrete pavements, ACI Structural Journal 98: 201-206.

DuPont. 1992. DuPont de Nemours and Co., Kevlar Data Sheet. Wilmington, DE.

El-Hacha, R.; Rizkalla, S. H. 2004. Near-surface-mounted fiberreinforced polymer reinforcements for flexural strengthening of oncrete structures, ACI Structural Journal 101(5): 717-727.

Engindeniz, M.; Kahn, L. F.; Zureick, A. H. 2005. Repair and strengthening of reinforced concrete beam-column joints: state of the art, ACI Structural Journal 102(2): 187-197.

Fam, A.; Greene, R.; Rizkalla, S. 2003a. Field applications of concrete-filled FRP tubes for marine piles, in Rizkalla, S.; Nanni, A. (Eds.). Field Applications of FRP Reinforcement: Case Sudies ACI SP-215. ACI, Farmington Hills, 161-180.

Fam, A.; Pando, M.; Filz, G.; Rizkalla, S. 2003b. Precast piles for route 40 bridge in Virginia using concrete-filled FRP tubes, PCI Journal 48: 32-45.

Faza, S. S.; GangaRao, H. V. S. 1992. Pre-and post-cracking deflection behaviour of concrete beams reinforced with fibre-reinforced plastic rebars, in Proceedings of the First International Conference on Advance Composite Materials in Bridges and Structures (ACMBS-I), Canadian Society of Civil Engineers, Sherbrooke, Cananda, 129-137.

FIB (Fédération Internationale du Béton). 2007. FRP reinforcement in RC structures. Technical report by TG 9.3. Lausanne: fib.

Gerritse, A. 1992. Durability criteria for non-metallic tendons in alkaline environment, in Neale, K. W.; Labossiere, P. (Eds.). First International Conference of Advanced Composite Materials in Bridges and Structures, Sherbrooke, Quebec, Canada, 129-137.

Gerritse, A.; Den Uijl, J. A. 1995. Long term behavior of Arapree, Non-Metallic (FRP) Reinforcements for Concrete Structures, FRPCS-2. Ghent, Belgium, 57-66.

Gribniak, V.; Kaklauskas, G.; Torres, L.; Daniunas, A.; Timinskas, E.; Gudonis, E. 2013. Comparative analysis of deformations and tension-stiffening in concrete beams reinforced with GFRP or steel bars and fibers, Composites Part B: Engineering 50: 158-170. http://dx.doi.org/10.1016/j.compositesb.2013.02.003 
Hawkins, G. F.; Patel, N. R.; Steckel, G. L. 1996. Failure analysis of highway bridge column composite overwraps, in First International Conference on Composites in Infrastructure, 15-17 January, 1996, Tucson, Arizona, 1126-1140.

Hoffard, T. A.; Malvar, L. J. 2005. Fiber-reinforced polymer composites in bridges: a state-of-the-art report (No. NFESC-TM2384-SHR). Naval Facilities Engineering command Port Hueneme ca Engineering Service Center.

Horn, M. H.; Riewald, P. G.; Zweben, C. H. 1977. Strength and durability characteristics of ropes and cables from Kevlar aramid fibers, in Oceans' 77 Conference Record, Third Combined Conference sponsored by the Marine Technology Society and the Institute of Electrical and Electronic Engineers, 17-19 October, 1977, Los Angeles, 313-324.

Hutchinson, R.; Tadros, G.; Kroman, J.; Rizkalla, S. 2003. Use of externally bonded FRP systems for rehabilitation of bridges in Western Canada, in Rizkalla, S.; Nanni, A. (Eds.). Field Applications of FRP Reinforcement: Case Studies ACI SP-215. ACI, Farmington Hills, 239-248.

Ilki, A.; Peker, O.; Karamuk, E.; Demir, C.; Kumbasar, N. 2008. FRP retrofit of low and medium strength circular and rectangular reinforced concrete columns, Journal of Materials in Civil Engineering 20(2): 169-188.

http://dx.doi.org/10.1061/(ASCE)0899-1561(2008)20:2(169)

JSCE. 1997. Recommendation for design and construction of concrete structures using continuous fiber reinforcing materials, concrete engineering series 23. Tokyo, Japan: JSCE (Japan Society of Civil Engineers).

Kato, Y.; Yamaguchi, T.; Nishimura, T.; Uomoto, T. 1997. Computational model for deterioration of aramid fibre by ultraviolet rays, in Proceedings of the 3rd International Symposium Non-Metallic (FRP) Reinforcement for Concrete Structures 2: 163-170.

Keller, T. 2003. Use of fibre reinforced polymers in bridge construction. Zurich, Switzerland: International Association for Bridge and Structural Engineering. $131 \mathrm{p}$.

Kim, Y. J.; Wight, R. G.; Green, M. F. 2008a. Flexural strengthening of RC beams with prestressed CFRP sheets: development of nonmetallic anchor systems, Journal of Composites for Construction 12(1): 35-43.

http://dx.doi.org/10.1061/(ASCE)1090-0268(2008)12:1(44)

Kim, Y. J.; Wight, R. G.; Green, M. F. 2008b. Flexural strengthening of RC beams with prestressed CFRP sheets: using nonmetallic anchor systems, Journal of Composites for Construction 12(1): 44-52.

http://dx.doi.org/10.1061/(ASCE)1090-0268(2008)12:1(35)

Lopez-Anido, R. 1997. Laurel Lick Bridge, FRP International 1997: 5-6.

Lu, X. Z.; Teng, J. G.; Ye, L. P.; Jiang, J. J. 2005. Bond-slip models for FRP sheets/plates bonded to concrete, Engineering Structures 27(6): 920-937. http://dx.doi.org/10.1016/j.engstruct.2005.01.014

Malvar, L. J. 1998. Durability of composites in reinforced concrete, CDCC 98: 1-12.

Miàs, C.; Torres, L.; Turon, A.; Barris, C. 2013a. Experimental study of immediate and time-dependent deflections of GFRP Reinforced concrete beams, Composite Structures 96: 279285. http://dx.doi.org/10.1016/j.compstruct.2012.08.052
Miàs, C.; Torres, L.; Turon, A.; Sharaky, I. A. 2013b. Effect of material properties on long-term deflections of GFRP reinforced concrete beams, Construction and Building Materials 41: 99-108.

http://dx.doi.org/10.1016/j.conbuildmat.2012.11.055

Micelli, F.; Nanni, A. 2004. Durability of FRP rods for concrete structures, Construction and Building Materials 18(7): 491503. http://dx.doi.org/10.1016/j.conbuildmat.2004.04.012

Mufti, A.; Erki, M.-A.; Jaeger, L. 1991. Advanced composite materials with application to bridges. Montréal: CSCE. 297 p.

Neale, K. W. 2000. FRPs for structural rehabilitation: a survey of recent progress, Progress in Structural Engineering and Materials 2(2): 133-138.

http://dx.doi.org/10.1002/1528-2716(200004/06)2:2<133::AIDPSE16>3.0.CO;2-C

NIIZhB. 2006. Concrete and reinforced concrete structures without prestressing, SP 52-101-2003. Moscow: NIIZhB (Reinforced Concrete Research and Technology Institute).

Niroomandi, A.; Maheri, A.; Maheri, M. R.; Mahini, S. S. 2010. Seismic performance of ordinary RC frames retrofitted at joints by FRP sheets, Engineering Structures 32(8): 23262336. http://dx.doi.org/10.1016/j.engstruct.2010.04.008

Nkurunziza, G.; Debaiky, A.; Cousin, P.; Benmokrane, B. 2005. Durability of GFRP bars: a critical review of the literature, Progress in Structural Engineering and Materials 7(4): 194209. http://dx.doi.org/10.1002/pse.205

Odagiri, T.; Matsumoto, K.; Nakai, H. 1997. Fatigue and relaxation characteristics of continuous aramid fiber reinforced plastic rods, in Proceedings of the Third International Symposium on Non-Metallic (FRP) Reinforcement for Concrete Structures (FRPRCS-3), 2: 14-16.

Oehlers, D. J.; Park, S. M.; Mohamed Ali, M. S. 2003. A structural engineering approach to adhesive bonding longitudinal plates to RC beams and slabs, Composites Part A: Applied Science and Manufacturing 34(9): 887-897. http://dx.doi.org/10.1016/S1359-835X(03)00153-2

Rizkalla, S.; Shehata, E.; Abdelrahman, A.; Tadros, G. 1998. A new generation: design and construction of a highway bridge with CFRP, Concrete International 20: 35-38.

Rizkalla, S.; Dawood, M.; Shahawy, M. 2006. Fiber-reinforced polymers for transportation and civil engineering infrastructure, Interstate Structures. $121 \mathrm{p}$.

Rizkalla, S. H.; Tadros, G. 1994. First smart highway bridge in Canada, Concrete International 16(6): 42-44.

Rostasy, F. 1997. On durability of FRP in aggressive environments, in Proceedings of the Third International Symposium on Non-Metallic (FRP) Reinforcement for Concrete Structures 2: 107-114.

Scheibe, M.; Rostasy, F. S. 1995. Stress-rupture of AFRP subjected to alkaline solutions and elevated temperature - experiments, Non-Metallic (FRP) Reinforcements for Concrete Structures, FRPCS-2. Ghent, Belgium, 67-73.

Schöck. 2006. Technical information Schöck Combar. Schöck Bauteile GmbH, Baden Baden, Germany. 23 p.

Seible, F.; Priestley, M. N.; Hegemier, G. A.; Innamorato, D. 1997. Seismic retrofit of RC columns with continuous carbon fiber jackets, Journal of Composites for Construction 1(2): 52-62. http://dx.doi.org/10.1061/(ASCE)1090-0268(1997)1:2(52) 
Sen, R.; Shahawy, M.; Rosas, J.; Sukumar, S. 1998. Durability of aramid pretensioned elements in a marine environment, ACI Structural Journal 95(5): 578-587.

Shahawy, M. A.; Beitelman, T.; Arockiasamy, M.; Sowrirajan, R. 1996a. Experimental investigation on structural repair and strengthening of damaged prestressed concrete slabs utilizing externally bonded carbon laminates, Composites Part B: Engineering 27(3): 217-224. http://dx.doi.org/10.1016/1359-8368(95)00043-7

Shahawy, M. A.; Arockiasamy, M.; Beitelman, T.; Sowrirajan, R. 1996b. Reinforced concrete rectangular beams strengthened with CFRP laminates, Composites Part B: Engineering 27(3): 225-233. http://dx.doi.org/10.1016/1359-8368(95)00044-5

Skuturna, T.; Valivonis, J.; Vainiūnas, P.; Marčiukaitis, G.; Daugevičius, M. 2008. Analysis of deflections of bridge girders strengthened by carbon fibre reinforcement, The Baltic Journal of Road and Bridge Engineering 3(3): 145-151. http://dx.doi.org/10.3846/1822-427X.2008.3.145-151

Slattery, K. 1994. Mechanistic model of the creep-rupture process in filamentary composites, in the Proceedings of Third Materials Engineering Conference, Infrastructure: New Materials and Methods of Repair, San Diego, CA, 215-222.

Smith, S. T.; Teng, J. G. 2002. FRP-strengthened RC beams. I: review of debonding strength models, Engineering Structures 24(4): 385-395.

http://dx.doi.org/10.1016/S0141-0296(01)00105-5

Sultan, M.; Hawkins, G.; Sheng, L. H. 1995. CALTRANS program for the evaluation of fiber reinforced plastics for seismic retrofit and rehabilitation of structures, in Proceedings, FHWA National Seismic Conference, 10-13 December, 1995, San Diego, California.

Taerwe, L. 1993. FRP developments and applications in Europe, in Nanni, A. (Ed.). Fibre Reinforcing Plastic for Concrete Structures. Elsevier, 99-114.
Takewaka, K.; Khin, M. 1996. Deterioration and stress-rupture of FRP rods in alkaline solution simulating as concrete environment, in The $2^{\text {nd }}$ International Conference of Advanced Composite Materials in Bridges and Structures edited by MM El-Bardy, Canadian Society for Civil Engineering, Montreal, Quebec, 647-656.

Tezuka, M. 1994. First Japanese AFRP Road Bridge, FRP International. $5 \mathrm{p}$.

Teng, J. G.; Chen, J. F.; Smith, S. T.; Lam, L. 2003. Behaviour and strength of FRP-strengthened RC structures: a state-of-theart review, Proceedings of the ICE-Structures and Buildings 156(1): 51-62. http://dx.doi.org/10.1680/stbu.2003.156.1.51

Teng, J. G.; Yu, T.; Wong, Y. L.; Dong, S. L. 2007. Hybrid FRP_ concrete-steel tubular columns: concept and behavior, Construction and Building Materials 21(4): 846-854. http://dx.doi.org/10.1016/j.conbuildmat.2006.06.017

Timinskas, E.; Jakstaite, R.; Gribniak, V.; Tamulenas, V.; Kaklauskas, G. 2013. Accuracy analysis of design methods for concrete beams reinforced with fiber reinforced polymer bars, Engineering Structures and Technologies 5(3): 123-133.

Tomosawa, F.; Nakatsuji, T.; Kimura, K.; Saka, K.; Kawaguchi, H. 1998. Evaluation of ACM reinforcement durability by exposure test, in American Society of Mechanical Engineers, $17^{\text {th }}$ International Conference on Offshore Mechanics and Arctic Engineering (USA). 9 p.

Tuakta, C. 2005. Use of fiber reinforced polymer composite in bridge structures: Doctoral dissertation, Massachusetts Institute of Technology.

Xiong, G. J.; Jiang, X.; Liu, J. W.; Chen, L. 2007. A way for preventing tension delamination of concrete cover in midspan of FRP strengthened beams, Construction and Building Materials 21(2): 402-408. http://dx.doi.org/10.1016/j.conbuildmat.2005.08.005

Wolff, R.; Miesser, H. J. 1989. New materials for prestressing and monitoring heavy structures, Concrete International 11(9): 86-89.

Eugenijus GUDONIS. PhD student at the Department of Bridges and Special Structures of Vilnius Gediminas Technical University (VGTU), Lithuania. BSc (2008) and MSc (2010) in Construction Engineering from VGTU. Research interests: numerical analysis of reinforced concrete structures.

Edgaras TIMINSKAS. PhD student at the Department of Bridges and Special Structures of VGTU, Lithuania. BSc (2007) and MSc (2009) in Construction Engineering from VGTU. Research interests: composite reinforcement.

Viktor GRIBNIAK. Senior Researcher at the Civil Engineering Research Centre of VGTU, Lithuania. PhD degree from VGTU. A member of the fib Task Group 4.1 Serviceability Models. The ASCE Moisseiff Award for a paper contributing to structural design (2013). Research interests: serviceability analysis and numerical modelling of reinforced concrete (RC) structures, innovative types of reinforcement for concrete.

Gintaris KAKLAUSKAS. Prof. Dr, the Head of the Department of Bridges and Special Structures of VGTU, Lithuania. PhD and Dr Sc degrees received from VGTU. Academician at the Lithuanian Academy of Science and a member of the fib Task Group 4.1 Serviceability Models. Recipient of Fulbright and Marie Curie (senior research category) fellowships. The ASCE Moisseiff Award for a paper contributing to structural design (2013). Research interests: various topics on reinforced concrete, particularly constitutive modelling and numerical simulation of reinforced concrete structures.

Aleksandr K. ARNAUTOV. Senior Researcher at the Institute of Polymer Mechanics (IMP) of the University of Latvia, Riga, Latvia. PhD degree obtained from IMP. Research interests: theoretical and experimental studies on the deformation and fracture of materials, mechanics of composite structure, test methods for determining the mechanical properties of composite materials.

Vytautas TAMULE்NAS. MSc student at the Department of Bridges and Special Structures of Vilnius Gediminas Technical University. Research interests: analysis of reinforced concrete structures under cyclic loading. 